
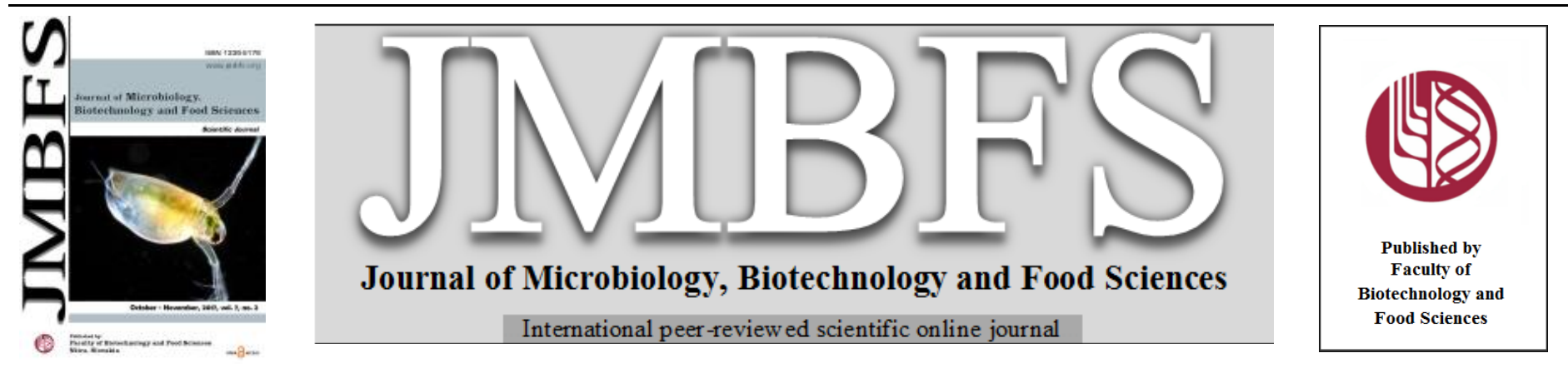

\title{
OPTIMIZATION OF ENHANCED PROBIOTIC SPORES PRODUCTION IN SUBMERGED CULTIVATION OF BACILLUS AMYLOLIQUEFACIENS B-1895
}

\author{
Tamar Khardziani ${ }^{1}$, Kakha Sokhadze ${ }^{1}$, Eva Kachlishvili ${ }^{l}$, Vladimir Chistyakov ${ }^{2}$, Vladimir Elisashvili ${ }^{l} *$
}

Address(es): DSc, Prof. Vladimir Elisashvili,

${ }^{1}$ Agricultural University of Georgia, Agmashenebeli alley 240, 0159 Tbilisi, Georgia, phone number: +995 555525499 .

${ }^{2}$ D.I. Ivanovsky Academy of Biology and Biotechnology of Southern Federal University, Stachki av. 194/1, 344090 Rostov-on-Don, Russia.

*Corresponding author: v.elisashvili@agruni.edu.ge

doi: 10.15414/jmbfs.2017.7.2.132-136

\section{ARTICLE INFO}

Received 20. 4. 2017

Revised 16. 8. 2017

Accepted 7. 9. 2017

Published 1. 10. 2017

Regular article open $\partial_{\text {ACCESS }}$

\begin{abstract}
The aim of this study was to gain a deeper fundamental knowledge on the physiology of B. amyloliquefaciens B-1895 for development of probiotic production technology through the submerged fermentation of renewable and inexpensive agro-industrial lignocellulosic biomass.

For comparison, bacilli cultivation was performed in the synthetic medium with different carbon sources. The highest yield of spores $\left(7.1 \times 10^{9} / \mathrm{mL}\right)$ was attained after $72 \mathrm{~h}$ of submerged cultivation of bacilli in the $0.4 \%$ glucose-containing medium. Substitution of glucose with various lignocellulosic materials at concentration of $40 \mathrm{~g} / \mathrm{L}$ yielded $2.3-10.8 \times 10^{9}$ spores $/ \mathrm{mL}$. After subsequent optimization, the developed simple medium containing milled corn cobs as a growth substrate and casein hydrolysate at concentration of $40 \mathrm{mM} \mathrm{N}$ provided formation of as high as $2.8 \times 10^{10}$ spore $/ \mathrm{mL}$ in shake-flasks experiments and $2.5 \times 10^{10}$ spores $/ \mathrm{mL}$ in a laboratory fermenter enabling the large scale production of low-cost probiotic for their biotechnological application. The study underlines importance for the efficient sporulation of carbon source depletion at the end of the exponential growth phase. Moreover, it shows that an exploitation of lignocellulosic materials with an appropriate chemical composition is a reasonable way to achieve high cell density and sporulation since bacilli secrete sufficient levels of glycosyl hydrolases for substrate saccharification to ensure bacterial culture with carbon and energy source.
\end{abstract}

Keywords: Probiotics, Bacillus amyloliquefaciens, spore production, submerged fermentation, carbon and nitrogen sources, cellulase

\section{INTRODUCTION}

Probiotics have only recently begun to receive a broad scientific and commercial interest. In addition to increasing demand of consumers for organic and naturally produced livestock, the main reason is a widespread use in animal feed of antibiotics as prophylactic and growth-promoting compounds which led to the development of antibiotic-resistant pathogens and decreased immune function, production losses, and the risk of zoonotic infections because of transference of antibiotic resistance genes from animal to human microbiota (Mathur and Singh, 2005). The application of probiotic preparations, i.e. cultures of the microorganisms, capable to create a natural protective barrier between animals and causative agents of infectious diseases became the most real natural alternative to traditional antibiotic therapies as well as to enhance animal productivity and improve product safety (Tuohy et al., 2007; Cutting, 2011).

Besides strains of Lactobacillus, Pediococcus, and Bifidobacterium, sporeforming Bacillus spp. have become more prevalent in livestock applications indicating favourable economic advantages, especially in the poultry industry (Hong et al., 2005; Aureli et al., 2011). Bacilli are widespread in the nature, they can be found in the normal intestinal flora of human and animals and are capable of germinating and re-sporulating in the gastrointestinal tract (Cutting, 2011). Moreover, these organisms are characterized by high adaptability to environmental conditions; their spores can withstand harsh environmental stress, have a long shelf life and thus can be stored in a state of dehydration (de Boer and Diderichsen, 1991). Furthermore, they have a capability of surviving the low $\mathrm{pH}$ of the gastric barrier and unlike Lactobacillus the entire dose of ingested bacteria may reach the small intestine intact (Barbosa et al., 2005; Tuohy et al., 2007). Finally, in their vegetative form, Bacillus spp. produce extracellular enzymes (proteases, cellulases, xylanases, pectinases, and lipase) that may enhance digestibility and absorption of nutrients in addition to overall immune function of the gut (Samanya and Yamauchi, 2002; Chen et al., 2009). However, analysis of literature data shows that only few bacteria have been extensively studied so far and current knowledge on their physiology is still limited in order to realize their biotechnological potential on industrial level. In particular, very little is known about physiological peculiarities of bacilli growth and spore production in lignocellulose fermentation. Moreover, information on hydrolytic enzymes production in lignocellulose fermentation by bacilli is scarce although polysaccharides are typically the main resource for bacterial growth and cellulases play a decisive role in steadily supplying carbon and energy source to the bacteria.

A high throughput approach was used for preliminary screening of 245 endospore-forming bacterial strains in order to identify Bacillus spp. isolates for usage as additives in the feed industry (Larsen et al., 2014). The spectrum of characteristics, such as antibiotic resistance, pathogen inhibition, sporulation, production of glycosyl hydrolases and biofilms showed that strains belonging to $B$. amyloliquefaciens, $B$. subtilis and $B$. mojavensis exhibited the best probiotic potential compared to $B$. licheniformis, $B$. megaterium and B. pumilus. Moreover, probiotic preparation Ecobiol ${ }^{\circledR}$ based on Bacillus amyloliquefaciens CECT5940 spores reduces the effect of the pathogenic bacteria Clostridium perfringens and Escherichia coli, and to improve the feed conversion rate in poultry (EFSA 2008). Recently, we have shown that Bacillus amyloliquefaciens B-1895 spores obtained after soybean solid-state fermentation stimulate the broilers' growth, improve feed conversion rate and body weight gain and quality (Chistyakov et al., 2015). Moreover, performed safety tests for toxigenic and mutagenic potential, co-aggregation capability with Escherichia coli and Pseudomonas aeruginosa, antibiotic resistance, tolerance to incubation at $0.3 \%$ bile salts and at $\mathrm{pH}$ 2.0-3.0 revealed a high potential of this strain for food and medical applications (AlGburi et al., 2016). Therefore, development of the low-cost and competitive technology of spore-forming probiotic production for application as a poultry dietary supplement became mandatory. This study was undertaken to gain a deeper fundamental knowledge on the physiology of B. amyloliquefaciens B-1895 for further development of such technology through the submerged fermentation of renewable and inexpensive agro-industrial lignocellulosic biomass abundantly available in Georgia. 


\section{MATERIALS AND METHODS}

\section{Strain and inoculum preparation}

Bacillus amyloliquefaciens B-1895 culture (soil isolate) deposited in the Russian National Collection of Industrial Microorganisms (RNCIM, Moscow, Russia) was used in this investigation. The strain was stored on the peptone-yeast agar medium in the Petri dishes at $4{ }^{\circ} \mathrm{C}$. For inoculum preparation, $B$ amyloliquefaciens B-1895 was grown for $24 \mathrm{~h}$ on a rotary shaker at $150 \mathrm{rpm}, 37$ ${ }^{\circ} \mathrm{C}$ in the nutrient medium of following composition $(\mathrm{g} / \mathrm{L})$ : glucose $-2.0, \mathrm{KH}_{2} \mathrm{PO}_{4}$ - 1.0, $\mathrm{MgSO}_{4}-0.5$, peptone - 2.0, yeast extract - 2.0, $\mathrm{pH}$ 7.0. The cells were then harvested and re-suspended in sterilized physiological saline to serve as inoculum for submerged fermentation.

\section{Cultivation conditions}

The submerged cultivation of B. amyloliquefaciens B-1895 was conducted using the Innova 44 shaker (New Brunswick Scientific, USA) at $37{ }^{\circ} \mathrm{C}$ and $150 \mathrm{rpm}$. One $\mathrm{mL}$ of properly diluted bacterial suspension [to have in inoculated medium $10^{6}$ colony-forming units $(\mathrm{CFU}) / \mathrm{mL}$ ] was used to inoculate the $250-\mathrm{mL}$ flasks containing $50 \mathrm{~mL}$ of the basal medium $(\mathrm{g} / \mathrm{L}): \mathrm{KH}_{2} \mathrm{PO}_{4}-1.0, \mathrm{MgSO}_{4} \cdot 7 \mathrm{H}_{2} \mathrm{O}-0.5$, yeast extract $-3.0 \mathrm{~g}$, peptone -3.0 . Xylose, glucose, sucrose, and glycerol in concentration of $5 \mathrm{~g} / \mathrm{L}$ were used as the carbon sources and wheat bran, ethanol production residue (EPR) from the wheat or corn grains, mandarin and banana peels, corn cobs, soybean, sunflower extraction cake, and sunflower oil cake in an amount of $40 \mathrm{~g} / \mathrm{L}$ were used as the bacilli growth substrates. All plant residues were dried at $50{ }^{\circ} \mathrm{C}$ and milled to powder. The initial $\mathrm{pH}$ of all media was adjusted to 7.0 prior to sterilization. Three inorganic $\left(\mathrm{KNO}_{3},\left(\mathrm{NH}_{4}\right)_{2} \mathrm{SO}_{4}\right.$ $\mathrm{NH}_{4} \mathrm{NO}_{3}$ ) and three organic nitrogen sources (peptone, yeast extract and casein hydrolysate) at concentration of $20 \mathrm{mM}$ as nitrogen were tested for optimum spores production. Controls lacking, respectively, carbon or nitrogen source were run in parallel. After 3 days of the submerged cultivations the solids were separated by centrifugation (Eppendorf 5417R, Germany) at 10,000 $\mathrm{g}$ for $5 \mathrm{~min}$ at $4{ }^{\circ} \mathrm{C}$. The supernatants were analysed for $\mathrm{pH}$, reducing sugars and cellulase activity. All experiments were performed twice using three replicates each time. All results are expressed as the mean $\pm \mathrm{SD}$. The mean values as well as standard deviations were calculated by the Excel program (Microsoft Office 2010 package) and only values of $p \leq 0.05$ were considered as statistically significant. After the nutrient medium optimization in shake-flasks experiments, a feasibility of scaled up probiotic production process was checked in a laboratory fermenter For this purpose, a fully equipped with $\mathrm{pH}$, temperature and $\mathrm{pO}_{2}$ probes $7 \mathrm{~L}$ stirred-tank fermenter LILFUS GX (Korea) with two Rushton impellers was used. The fermenter was filled with $5 \mathrm{~L}$ of the optimized medium $(\mathrm{g} / \mathrm{L})$ : milled corn cobs - 40.0, peptone - 8.0; $\mathrm{KH}_{2} \mathrm{PO}_{4}-1.0, \mathrm{MgSO}_{4} \cdot 7 \mathrm{H}_{2} \mathrm{O}-0.5$, polypropylene glycol $2000-2.5 \mathrm{~mL}, \mathrm{pH}-7.0$. The fermenter was sterilized (121 ${ }^{\circ} \mathrm{C}, 40 \mathrm{~min}$ ) and inoculated with the bacterial culture (final concentration - $2 \times 10^{6}$ $\mathrm{CFU} / \mathrm{mL}$ ). Fermentation was carried out without baffles at $37^{\circ} \mathrm{C}$, impeller speed $250 \mathrm{rpm}$, airflow rate $0.5-1.0 \mathrm{v} / \mathrm{v} / \mathrm{min}$, and free $\mathrm{pH}$. During fermentation process samples were collected daily and analyzed for number of vegetative cells, spore concentration, cellulase activity and purity using a light microscope.

\section{Spores count}

An amount of $1 \mathrm{~mL}$ of each culture was taken from the flasks and suspended in 9 $\mathrm{mL}$ of normal saline, vortexed and heated at $80{ }^{\circ} \mathrm{C}$ for $10 \mathrm{~min}$ to kill the vegetative cells. Then the samples were prepared by serial 10 -fold dilution and vortex to obtain homogeneous suspension. $100 \mu \mathrm{L}$ were taken from the $10^{6}-10^{8}$ times diluted suspensions and spread plated onto the sterile agar medium of following composition $(\mathrm{g} / \mathrm{L})$ : glucose - 2.0, $\mathrm{KH}_{2} \mathrm{PO}_{4}-1.0, \mathrm{MgSO}_{4}-0.5$, peptone - 2.0, yeast extract - 2.0, agar-agar - 17.0, pH 7.0. The Petri dishes were incubated for $24 \mathrm{~h}$ and $48 \mathrm{~h}$ and the single colonies which appeared on the plates were counted. The average values were taken to calculate the number of spores per $\mathrm{mL}$.

\section{Cellulase activity assay}

The supernatants obtained after biomass separation were analysed for the carboxymethyl cellulase (CMCase) activity according to the IUPAC recommendations with $1 \%$ low-viscosity carboxymethyl cellulose in $50 \mathrm{mM}$ citrate buffer ( $\mathrm{pH} 5.0$ ) at $50{ }^{\circ} \mathrm{C}$ for $10 \mathrm{~min}$ (Ghose, 1981). Glucose standard curve was used to calculate the cellulase activity. In all assays the release of reducing sugars (RS) was measured using the dinitrosalicylic acid reagent method (Miller, 1959). One unit of enzyme activity was defined as the amount of enzyme, releasing $1 \mu \mathrm{mol}$ of glucose per minute.

\section{RESULTS AND DISCUSSION}

To develop an appropriate technology of spore-forming probiotic production there is a need to understand their nutrient requirements for growth and sporulation. Sporulation of Bacillus spp. strains is highly dependent on the experimental conditions, i.e., medium composition, $\mathrm{pH}$, aeration, temperature (Monteiro et al., 2005). However, an information on the physiology of spore production is limited obviously because their protection through patents. In this study, effect of carbon and nitrogen sources and their concentrations on the $B$. amyloliquefaciens B-1895 spores yield was established.

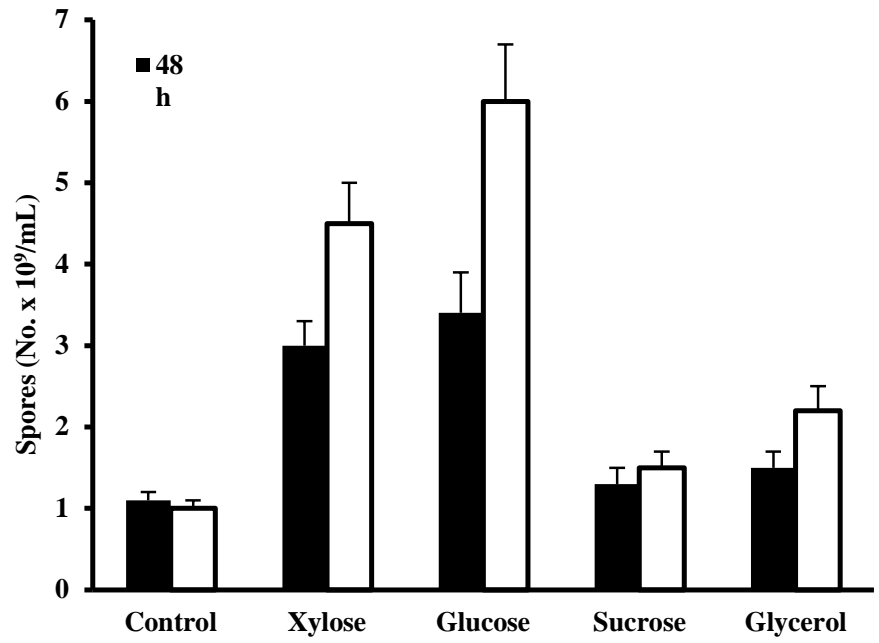

Figure 1 Effect of carbon sources $(0.5 \%)$ on the B. amyloliquefaciens B-1895 spore production after $48 \mathrm{~h}$ and $72 \mathrm{~h}$ of submerged cultivation.

\section{Effect of carbon source on B. amyloliquefaciens B-1895 spore production}

To evaluate a sporulation capability of B. amyloliquefaciens B-1895 in dependence on carbon source the bacilli cultivation was performed in the basal synthetic medium. Control medium without carbon source provided poor bacterial growth at the expense of available yeast extract and peptone while spores yield reached only $1.1 \times 10^{9}$ (Fig. 1). Supplementation of the control medium with any tested carbon source at concentration of $0.5 \%$ stimulated both bacterial growth (data not shown) and spores production, although with different extent. The highest yield of spores $\left(6 \times 10^{9}\right)$ was attained after $72 \mathrm{~h}$ of submerged cultivation of bacilli in the glucose-containing medium. Xylose also served as an appropriate carbon source for spore formation. Almost 3-fold lower spore number was detected in bacteria cultivation in the presence of glycerol while sucrose appeared to be the poorest carbon source for B. amyloliquefaciens B1895 apparently because of low sucrase activity. Moreover, it is possible that low $\mathrm{pH}$ in the media with glycerol and sucrose (5.6 and 6.0, respectively) was another reason of low sporulation efficiency. Finally, it is worth noting that the carbon source addition to the control medium shifted the time of maximum spore yield from $48 \mathrm{~h}$ to $72 \mathrm{~h}$

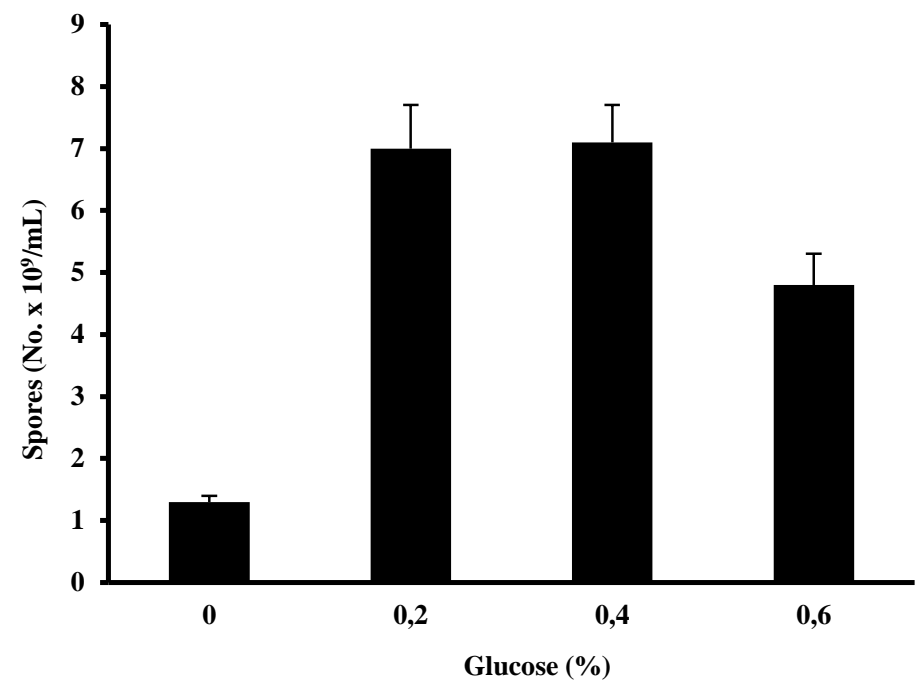

Figure 2 Effect of glucose concetration on the B. amyloliquefaciens B-1895 spore accumulation.

Subsequently, glucose concentration effect on the probiotic production was studied. The data received showed that even the lowest concentration $(0.2 \%)$ of carbon source 5-fold increased the spore yield as compared with the control 
medium (Fig. 2). Maximum concentration of spores (7.1 x 109) was achieved when the medium contained $0.4 \%$ glucose; further increase of the carbon source concentration caused a decrease of spore yield. Analogically, an increase in glucose concentration up to $5 \mathrm{~g} / \mathrm{L}$ led to an increase of the maximum vegetative cell and spore concentration in cultivation of $B$. subtilis, while initial glucose concentrations higher than $5 \mathrm{~g} / \mathrm{L}$ inhibited sporulation (Monteiro et al., 2005) Regarding the production of spores and sporulation efficiencies, glucose $(11 \mathrm{~g} / \mathrm{L})$ was the only factor that had a significant negative effect on these variables in cultivation of B. subtilis EA-CB0575 (Posada-Uribe et al., 2015). It is important to note that in our experiments the complete glucose depletion at the end of the cultivation was observed in all media with the exclusion of $0.6 \%$ glucosecontaining medium where $0.3 \mathrm{mg} / \mathrm{mL}$ of the sugar was detected after $72 \mathrm{~h}$ growth. It is evident that the carbon source depletion is the main stimulus for sporulation by B. amyloliquefaciens B-1895. Therefore, the concentration of glucose in the culture medium should be reduced to increase the sporulation efficiency and spore yield

\section{Effect of lignocellulosic substrates on B. amyloliquefaciens B-1895 spore production}

The cost of probiotic production could be lowered through two approaches - by significant increasing spore yield and by using cheap raw materials as medium components. To achieve this aim, several agro-industrial wastes/by-product abundantly available in Georgia have been used in this study. Table 1 shows the results after three days of submerged fermentation of selected lignocellulosic materials. All the tested substrates ensured good visual growth of bacilli. With the exclusion of mandarin peels, their fermentation accompanied with a significant increase of medium $\mathrm{pH}$ by the end of cultivation. Among the tested growth substrates, corn cobs followed by EPR from wheat grains provided the highest yield of spores (1.5-fold higher as compared with the glucose-containing medium). However, the banana peels and wheat straw appeared to be poor growth substrates for the spores' formation. It is interesting that $B$ amyloliquefaciens B-1895 expressed comparatively low endoglucanase activity in fermentation of the tested materials, although it was rather higher as compared with $B$. subtilis strain MU S1 (Sreena et al., 2016). Nevertheless, in combination with other carbohydrases it obviously ensured the bacterial culture with required carbon source since the reducing sugars content in majority media reached 0.1 $0.4 \mathrm{~g} / \mathrm{L}$.

In the literature, scarce information describing the effect of lignocellulosic substrates on the bacilli spores' formation is available. In particular, among four growth substrates tested for submerged fermentation by two Bacillus KKU02 and KKU03 strains, cassava root supported better spores' production as compared with basal nutrient broth (Wangka-Orm et al., 2014). These strains accumulated 8.32 and $1.35 \times 10^{8}$ spores $/ \mathrm{mL}$, respectively, at the optimal cassava concentration of $100 \mathrm{~g} / \mathrm{L}$. Combination of tapioca $(16.7 \mathrm{~g} / \mathrm{L})$ with lactose $(12.7 \mathrm{~g} / \mathrm{L})$ in nutrient medium for submerged cultivation of $B$. amyloliquefaciens B128 resulted in spore yield of $5.92 \times 10^{8} / \mathrm{mL}$ (Rao et al., 2007). The comparison of these results indicates that our B. amyloliquefaciens B-1895 strain producing in submerged fermentation of lignocellulose 2.3-10.8 $\times 10^{9}$ spores $/ \mathrm{mL}$ is an efficient sporeforming bacterium with industrially relevant properties.

\begin{tabular}{lcccc} 
Table 1 Effect of lignocellulosic substrates on B. amyloliquefaciens B-1895 spores' accumulation and cellulase activity \\
\hline \multirow{2}{*}{ Substrate } & $\begin{array}{c}\text { Final } \\
\mathrm{pH}\end{array}$ & $\begin{array}{c}\mathrm{RS}, \\
\mathrm{mg} / \mathrm{mL}\end{array}$ & $\begin{array}{c}\text { Spores, } \\
\text { No. x } 10^{9} / \mathrm{mL}\end{array}$ & $\begin{array}{c}\text { CMCase, } \\
\mathrm{UL}\end{array}$ \\
\hline Banana peels & $8.8 \pm 0.1$ & $0.3 \pm 0.03$ & $2.4 \pm 0.3$ & $0.3 \pm 0.03$ \\
Corn cobs & $8.0 \pm 0.1$ & $0.1 \pm 0.02$ & $10.8 \pm 0.8$ & $0.4 \pm 0.05$ \\
EPR, corn grains & $8.3 \pm 0.1$ & $0.1 \pm 0.02$ & $3.6 \pm 0.3$ & $0.4 \pm 0.04$ \\
EPR, wheat grains & $9.0 \pm 0.1$ & $0.1 \pm 0.01$ & $9.6 \pm 0.6$ & $0.4 \pm 0.03$ \\
Mandarin peels & $6.8 \pm 0.2$ & $0.4 \pm 0.03$ & $8.2 \pm 0.8$ & $0.7 \pm 0.09$ \\
Soybean & $9.0 \pm 0.1$ & $0.1 \pm 0.02$ & $7.7 \pm 0.5$ & $0.3 \pm 0.02$ \\
Sunflower extraction cake & $9.0 \pm 0.1$ & $0.1 \pm 0.01$ & $8.9 \pm 0.5$ & $0.5 \pm 0.04$ \\
Sunflower oil cake & $8.5 \pm 0.1$ & $0.1 \pm 0.01$ & $3.6 \pm 0.2$ & $0.2 \pm 0.03$ \\
Wheat bran & $9.0 \pm 0.1$ & $0.3 \pm 0.02$ & $9.0 \pm 0.6$ & $0.3 \pm 0.04$ \\
Wheat straw & $8.5 \pm 0.1$ & 0 & $2.3 \pm 0.2$ & $0.2 \pm 0.02$ \\
\hline
\end{tabular}

EPR from wheat grains and corn cobs were selected for subsequent experiments and the B. amyloliquefaciens B-1895 spore accumulation was assessed in dependence on their concentration in the nutrient medium. The results in Table 2 show that the final $\mathrm{pH}$ values faintly depended on the substrate concentration. When the growth substrates concentration elevated from 1 to $4 \%$ the spore yield also gradually increased and the spores' number at 4\% substrate almost 3 -fold exceeded that at $1 \%$ concentration. However, the further increase of lignocellulose concentration rather inhibited the spore production. Between the two tested substrates corn cobs provided the highest yield of spores. Fermentation of this substrate accompanied with inconsiderable increase of the medium $\mathrm{pH}$ favoring the bacterial culture development. Therefore, in subsequent experiments the corn cobs at concentration of $40 \mathrm{~g} / \mathrm{L}$ were used as growth substrate for $B$ amyloliquefaciens B-1895 cultivation and spore production.

Table 2 Effect of substrate concentration on the B. amyloliquefaciens B-1895 spore production and cellulase activity

\begin{tabular}{lcccc}
$\begin{array}{l}\text { Substrate, } \\
\%\end{array}$ & $\begin{array}{c}\text { Final } \\
\mathrm{pH}\end{array}$ & $\begin{array}{c}\mathrm{RS}, \\
\mathrm{mg} / \mathrm{mL}\end{array}$ & $\begin{array}{c}\text { CMCase, } \\
\mathrm{U} / \mathrm{mL}\end{array}$ & $\begin{array}{c}\text { Spores, } \\
\text { No. } \times 10^{9} / \mathrm{mL}\end{array}$ \\
\hline EPR, wheat grains & & & & \\
1.0 & $9.2 \pm 0.1$ & $0.1 \pm 0.01$ & $0.2 \pm 0.03$ & $3.2 \pm 0.2$ \\
2.0 & $9.1 \pm 0.1$ & $0.1 \pm 0.01$ & $0.4 \pm 0.03$ & $6.5 \pm 0.4$ \\
3.0 & $9.1 \pm 0.1$ & $0.3 \pm 0.02$ & $0.5 \pm 0.04$ & $7.6 \pm 0.6$ \\
4.0 & $9.2 \pm 0.1$ & $0.3 \pm 0.02$ & $0.5 \pm 0.05$ & $9.1 \pm 0.7$ \\
6.0 & $9.1 \pm 0.1$ & $0.4 \pm 0.04$ & $0.6 \pm 0.04$ & $6.8 \pm 0.7$ \\
Corn cobs & & & \\
1.0 & $8.1 \pm 0.1$ & $0.1 \pm 0.01$ & $0.1 \pm 0.01$ & $4.3 \pm 0.4$ \\
2.0 & $7.9 \pm 0.1$ & $0.1 \pm 0.01$ & $0.2 \pm 0.03$ & $7.3 \pm 0.6$ \\
3.0 & $7.7 \pm 0.1$ & $0.2 \pm 0.01$ & $0.3 \pm 0.04$ & $11.0 \pm 0.9$ \\
4.0 & $7.8 \pm 0.1$ & $0.3 \pm 0.02$ & $0.5 \pm 0.04$ & $11.6 \pm 1.1$ \\
6.0 & $8.0 \pm 0.1$ & $0.4 \pm 0.02$ & $0.5 \pm 0.05$ & $10.3 \pm 1.0$ \\
\hline
\end{tabular}

\section{Effect of nitrogen sources}

Several inorganic salts and organic compounds were tested as an additional nitrogen source to available in the corn cobs nitrogen. The results in Table 3 reveal several general features. Firstly, the substrate fermentation in the presence of peptone, potassium and ammonium nitrate accompanied with an increase of the medium $\mathrm{pH}$ while the presence of ammonium sulphate caused acidification of the medium. Secondly, the corn cobs without additional nitrogen source represent an excellent growth substrate providing accumulation of $7.2 \times 10^{9}$ spores $/ \mathrm{mL}$
Thirdly, the yield of spores largely varied in culture of B. amyloliquefaciens B1895 when bacilli were grown under different nitrogen sources. In general, the yields of spores were increased by supplementation of the medium with organic nitrogen sources. Among them, casein hydrolyzate provided 3-fold increase of spore number as compered with the control medium. Among inorganic compounds, ammonium sulphate and ammonium nitrate rather inhibited the sporulation process; at the same time, $\mathrm{KNO}_{3}$ appeared to be the best source of nitrogen favoring more than 3 -fold increase of spore yield. On the contrary, in experiments with B. subtilis ammonium sulfate (4.54\%) in combination with 
corn flour (1.2\%) gave a maximum spore production (Shi and Zhu, 2007) Moreover, using a response surface methodology Rao et al. (2007) optimized the medium composition for maximum spore production by $B$. amyloliquefaciens B128 and showed that a mixture of $\left(\mathrm{NH}_{4}\right)_{2} \mathrm{SO}_{4}$ and peptone at concentrations of
1.8 and $8.0 \mathrm{~g} / \mathrm{L}$, respectively, provided the highest yield of this microorgamism spores.

Table 3 Effect of nitrogen sources on the B. amyloliquefaciens B-1895 spore production and cellulase activity

\begin{tabular}{lcccc}
\hline Nitrogen sources & $\begin{array}{c}\text { Final } \\
\mathrm{pH}\end{array}$ & $\begin{array}{c}\mathrm{RS}, \\
\mathrm{mg} / \mathrm{mL}\end{array}$ & $\begin{array}{c}\text { CMCase, } \\
\text { U/mL }\end{array}$ & $\begin{array}{c}\text { Spores, } \\
\text { No. x } 10^{9} / \mathrm{mL}\end{array}$ \\
\hline Control & $7.0 \pm 0.1$ & $0.2 \pm 0.01$ & $0.24 \pm 0.03$ & $7.2 \pm 0.9$ \\
$\mathrm{KNO}_{3}$ & $8.4 \pm 0.1$ & $0.1 \pm 0.01$ & $0.44 \pm 0.06$ & $23.4 \pm 2.7$ \\
$\left(\mathrm{NH}_{4}\right)_{2} \mathrm{SO}_{4}$ & $6.5 \pm 0.2$ & $0.3 \pm 0.02$ & $0.55 \pm 0.04$ & $5.3 \pm 0.8$ \\
$\mathrm{NH}_{4} \mathrm{NO}_{3}$ & $8.0 \pm 0.1$ & $0.1 \pm 0.02$ & $0.43 \pm 0.05$ & $7.0 \pm 0.7$ \\
Peptone & $7.7 \pm 0.1$ & $0.1 \pm 0.01$ & $0.52 \pm 0.04$ & $10.7 \pm 1.2$ \\
Yeast extract & $7.2 \pm 0.1$ & $0.2 \pm 0.01$ & $0.41 \pm 0.04$ & $15.0 \pm 2.0$ \\
Casein hydrolysate & $7.0 \pm 0.1$ & $0.1 \pm 0.01$ & $0.51 \pm 0.05$ & $20.3 \pm 2.1$ \\
\hline
\end{tabular}

When nitrogen concentration in the nutrient medium in the form of casein hydrolyzate increased from 0 to $40 \mathrm{mM}$ the number of produced spores gradually increased from $5.2 \times 10^{9} / \mathrm{mL}$ to $28 \times 10^{9} / \mathrm{mL}$ (Table 4). Further elevation of nitrogen source concentration to $80 \mathrm{mM}$ obviously delayed the development of the bacterial culture and the sporulation process since after $72 \mathrm{~h}$ of submerged fermentation of corn cobs the spore yield was even lower than that in control medium without additional nitrogen. It is worth noting that the reducing sugars content in all media was equal while the medium $\mathrm{pH}$ at the highest concentration of casein hydrolyzate was significantly higher than in other media. The measurement of endoglucanase activity revealed that the elevation of nitrogen content from 0 to $20-40 \mathrm{mM}$ favored extracellular cellulase activity accumulation. However, we assume that this picture may simply be due to a higher biomass production and it is not related to a stimulation of endoglucanase secretion.

Table 4 Effect of casein hydrolysate concentration on the B. amyloliquefaciens B-1895 spore production and cellulase activity

\begin{tabular}{llllc}
\hline $\begin{array}{l}\text { Nitrogen, } \\
\mathrm{mM}\end{array}$ & $\begin{array}{l}\text { Final } \\
\mathrm{pH}\end{array}$ & $\begin{array}{l}\mathrm{RS}, \\
\mathrm{mg} / \mathrm{mL}\end{array}$ & $\begin{array}{l}\text { CMCase, } \\
\mathrm{U} / \mathrm{mL}\end{array}$ & $\begin{array}{l}\text { Spores, } \\
\text { No. } \times 10^{9} / \mathrm{mL}\end{array}$ \\
\hline 0 & $7.0 \pm 0.1$ & $0.2 \pm 0.01$ & $0.21 \pm 0.03$ & $5.2 \pm 0.4$ \\
10 & $7.0 \pm 0.1$ & $0.2 \pm 0.01$ & $0.28 \pm 0.03$ & $7.9 \pm 0.8$ \\
20 & $7.0 \pm 0.1$ & $0.2 \pm 0.02$ & $0.46 \pm 0.05$ & $16.7 \pm 2.0$ \\
40 & $7.3 \pm 0.1$ & $0.2 \pm 0.01$ & $0.47 \pm 0.05$ & $28.0 \pm 3.2$ \\
80 & $8.0 \pm 0.1$ & $0.2 \pm 0.02$ & $0.42 \pm 0.06$ & $3.1 \pm 0.5$ \\
\hline
\end{tabular}

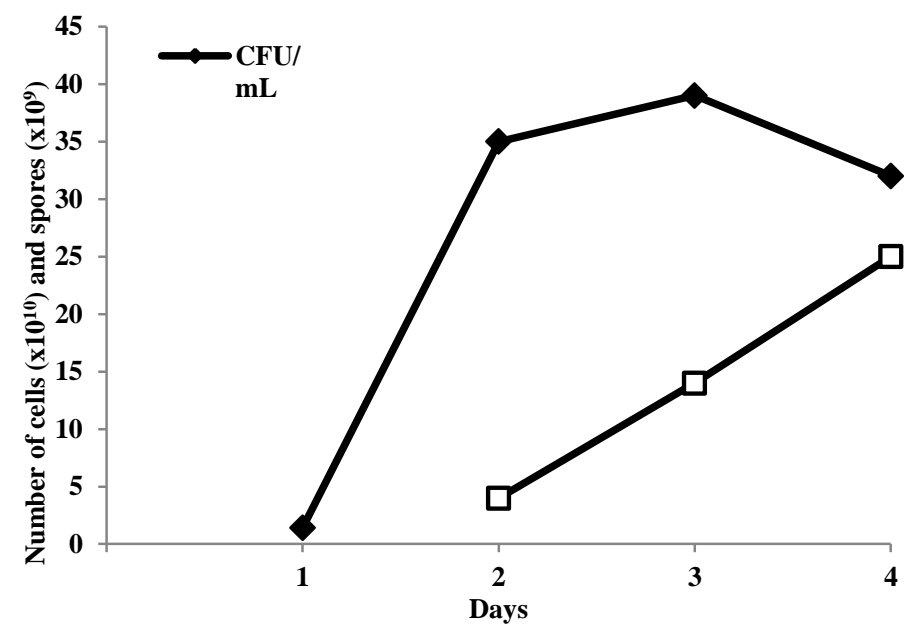

Figure 3 Kinetics of vegetative cells and spore accumulation in $B$ amyloliquefaciens $\mathrm{B}-1895$ cultivation in fermenter.

\section{Cultivation of B. amyloliquefaciens B-1895 in fermenter}

To verify a validity of developed medium for scaled up process of probiotic production, the $B$. amyloliquefaciens B-1895 cultivation was carried out in a fermenter filled with an optimized medium. During entire period of submerged fermentation the agitation speed was constant $(250 \mathrm{rpm})$ while the aeration rate was $0.5 \mathrm{~L} / \mathrm{L} / \mathrm{min}$ during the first day, then it was increased to $1.0 \mathrm{~L} / \mathrm{L} / \mathrm{min}$. Application of these conditions prevented bacterial cells sedimentation and provided sufficient dispersion of air. The data received showed that the bacilli multiplication occurred very rapidly during the first day of submerged fermentation and after $24 \mathrm{~h}$ the vegetative cells number increased from $2 \times 10^{6}$ $\mathrm{CFU} / \mathrm{mL}$ to $1.4 \times 10^{10} \mathrm{CFU} / \mathrm{mL}$ (Fig. 3). However, no spore production was observed by this time. During the second day of fermentation the vegetative cells number increased to $3.5 \times 10^{10} \mathrm{CFU} / \mathrm{mL}$ and after $48 \mathrm{~h}$ we detected $4 \times 10^{9}$ spores/mL. In subsequent cultivation the B. amyloliquefaciens B-1895 cells number increased insignificantly after $72 \mathrm{~h}$ and it decreased from $3.9 \times 10^{10}$ $\mathrm{CFU} / \mathrm{mL}$ to $3.2 \times 10^{10} \mathrm{CFU} / \mathrm{mL}$ after $96 \mathrm{~h}$ fermentation. By contrast, the spore number continued to increase with maximum yield after 4 days $\left(25 \times 10^{9}\right.$ spores $/ \mathrm{mL}$ ). It is worth noting that the sporulation efficiency increased from $1.1 \%$ after $48 \mathrm{~h}$ cultivation to $7.8 \%$ after $96 \mathrm{~h}$. Good sporulation (10-95\% after only 24 $\mathrm{h}$ incubation) was observed for the isolates of $B$. amyloliquefaciens, $B$ mojavensis and B. subtilis (Larsen et al., 2014). Poor sporulation ability of less than $10 \%$ after $48 \mathrm{~h}$ of incubation was found for B. licheniformis and B. pumilus, whereas none of the $B$. megaterium strains released spores at the assay conditions. Sporulation of commercial probiotic B. subtilis C-3102 and B. cereus var. toyoi was insignificant, comprising less than $5 \%$ after $72 \mathrm{~h}$. Moreover, the authoes showed that the spore percentage of B. amyloliquefaciens ssp. strains correlated significantly with biofilm production. In experiments with $B$. subtilis the sporulation efficiency in batch cultivation achieved $40.9 \%$ when glucose concentration was $3.5 \mathrm{~g} / \mathrm{L}$ and it gradually decreased to $17 \%$ with elevation of carbon source concentration to $20 \mathrm{~g} / \mathrm{L}$ while in fed batch cultivation $20.5 \%$ sporulation efficiency was observed (Monteiro et al., 2005). In another study, cultivation of $B$. subtilis EA-CB0575 in medium with $2.0 \mathrm{~g}$ glucose/L gave the highest spore cell density $\left(1.87 \times 10^{9}\right)$ and the highest sporulation efficiency $(93.2$ $\%)$ (Posada-Uribe et al., 2015). Apparently, the sporulation rate of the tested $B$. amyloliquefaciens B-1895 can be enhanced; therefore, further study should be performed in fermenter to significantly increase it.

\section{CONCLUSION}

Our findings presented in this study provide new knowledge on $B$ amyloliquefaciens B-1895 physiology and demonstrate that the optimization of cultivation conditions to achieve high probiotic yield is feasible. High yields of spores were obtained in submerged fermentation of cheap lignocellulosic wastes by this bacillus. After subsequent optimization, the developed simple medium provided formation of $2.8 \times 10^{10}$ spore $/ \mathrm{mL}$ and it enables the large scale production of low-cost probiotic for their biotechnological applications. The obtained yield represents the highest value relative to those reported in the literature for Bacillus spp. spore yields which varied from $1.0 \times 10^{5}$ spores $/ \mathrm{mL}$ (Cayuela et al., 1993) to $1.56 \times 10^{10}$ spores $/ \mathrm{mL}$ for B. subtilis (Chen et al., 2010) and $3.82 \times 10 \%$ for B. amyloliquefaciens B128 (Tseng et al., 2008). Moreover, the study underlines importance of carbon source depletion at the end of the exponential growth phase for the efficient sporulation. In relation with this, exploitation of lignocellulosic materials with an appropriate for selected bacilli composition is a reasonable way to achieve high cell density and sporulation since bacilli secrete sufficient levels of glycosyl hydrolases for substrate saccharification to ensure bacterial culture with required carbon and energy source. This approach will likely be applicable to cultivate other Bacillus spp. 
Acknowledgments: The authors are grateful for the financial support provided in the applied science project AR/106/7-280/14 by the Shota Rustaveli National Science Foundation, Georgia.

\section{REFERENCES}

AlGburi, A., Volski, A., Cugini, C., Walsh, E.M., Chistyakov, V.A., Mazanko, M.S., Bren, A.B., Dicks, L.M.T., \& Chikindas, M.L. (2016). Safety properties and probiotic potential of Bacillus subtilis KATMIRA1933 and Bacillus amyloliquefaciens B-1895. Advances in Microbiology, 6(6), 432-452. http://dx.doi.org/10.4236/aim.2016.66043

Aureli, P., Capurso, L., Castellazzi, A.M., Clerici, M., Giovannini, M., Morelli, L., Poli, A., Pregliasco, F., Salvili, F., \& Zuccotti, G.V. (2011). Probiotics and health: an evidence-based review. Pharmacological Research, 63(5), 366-376. http://dx.doi.org/10.1016/j.phrs.2011.02.006

Barbosa, T.M., Serra, C.R., La Ragione, R.M., Woodward, M.J., \& Henriques, A.O. (2005). Screening for Bacillus isolates in the broiler gastrointestinal tract. Applied and Environmental Microbiology, 71(2), 968-978. http://dx.doi.org/10.1128/AEM.71.2.968-978.2005

Cayuela, C., Kenichi, K., Park, Y. S., Ijima, S., \& Kobayashi, T. (1993). Insecticide production by recombinant Bacillus subtilis 1A96 in fed-batch culture with control of glucose concentration. Journal of Fermentation and Bioengineering. 75(5), 383-386. http://dx.doi.org/10.1016/0922-338x(93)90139y

Chen, K.L., Kho, W.L., You, S.H., Yeh, R.H., Tang, S.W., \& Hsieh, C.W. (2009). Effects of Bacillus subtilis var. natto and Saccharomyces cerevisiae mixed fermented feed on the enhanced growth performance of broilers. Poultry Science, 88(2), 309-315. http://dx.doi.org/10.3382/ps.200800224

Chen, Z.M., Li, Q., Liu, H.M., Yu, N., Xie, T.-J., Yang, M.-Y., Shen, P., \& Chen, X.-D. (2010). Greater enhancement of Bacillus subtilis spore yields in submerged cultures by optimization of medium composition through statistical experimental designs. Applied Microbiology and Biotechnology, 85(5), 1353-1360. http://dx.doi.org/10.1007/s00253-009-2162-x

Chistyakov, V., Melnikov, V., Chikindas, M.L., Khutsishvili, M., Chagelishvili, A., Bren, A., Kostina, N., Cavera, V., \& Elisashvili, V. (2015) Poultry-beneficial solid-state Bacillus amyloliquefaciens B-1895 fermented soy bean formulation. Bioscience of Microbiota, Food and Health, 34(1), 25-28. http://dx.doi.org/10.12938/bmfh.2014-012

Cutting, S.M. (2011). Bacillus probiotics. Food Microbiology, 28(2), 214-220. http://dx.doi.org/10.1016/j.fm.2010.03.007

de Boer, A.S., \& Diderichsen, B. (1991). On the safety of Bacillus subtilis and B. amyloliquefaciens: a review. Applied Microbiology and Biotechnology, 36(1), 1 4. http://dx.doi.org/10.1007/bf00164689

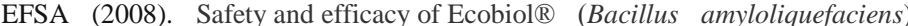
as feed additive for chickens for fattening - Scientific Opinion of the Panel on Additives and Products or Substances used in Animal Feed. EFSA Journal, 6(8), 773, 1-13. http://www.efsa.europa.eu/en/scdocs/doc/773

Ghose, T.K. (1987). Measurement of cellulase activities. Pure and Applied Chemistry, 59(2), 257-268. http://dx.doi.org/10.1351/pac198759020257

Hong, H.A., Duc, L.H., \& Cutting, S.M. (2005). The use of bacterial spore formers as probiotics. FEMS Microbiology Review, 29(4), 813-835. http://dx.doi.org/10.1016/j.femsre.2004.12.001

Larsen, N., Thorsen, L., Kpikpi, E.N., Stuer-Lauridsen, B., Cantor, M.D. Nielsen, B., Brockmann, E., Derkx, P.M.F., \& Jespersen L. (2014). Characterization of Bacillus spp. strains for use as probiotic additives in pig feed. Applied Microbiology and Biotechnology, 98(3), 1105-1118. http://dx.doi.org/10.1007/s00253-013-5343-6

Mathur, S., \& Singh, R. (2005). Antibiotic resistance in food lactic acid bacteria - a review. International Journal of Food Microbiology, 5(3), 281-295. http://dx.doi.org/10.1016/j.ijfoodmicro.2005.03.008

Miller, G.L. (1959). Use of dinitrosalicylic acid reagent for determination of reducing sugar. Analytical Chemistry, 31(3), 426-428. http://dx.doi.org/10.1021/ac60147a030

Monteiro, S.M., Clemente, J.J., Henriques, A.O., Gomes, R.J., Carrondo, M.J., \& Cunha, A.E. (2005). A procedure for high-yield spore production by Bacillus subtilis. Biotechnology Progress, 21(4), 1026-1031 http://dx.doi.org/10.1021/bp050062z

Posada-Uribe, L.F., Romero-Tabarez, M., \& Villegas-Escobar, V. (2015). Effect of medium components and culture conditions in Bacillus subtilis EA-CB0575 spore production. Bioprocess and Biosystems Engineering, 38(10), 1879-1888. http://dx.doi.org/10.1007/s00449-015-1428-1

Rao, Y.K., Tsay, K.-J., Wu, W.-S., \& Tzeng, Y.-M. (2007). Medium optimization of carbon and nitrogen sources for the production of spores from Bacillus amyloliquefaciens B128 using response surface methodology. Process Biochemistry, 42(4), 535-541. http://dx.doi.org/10.1016/j.procbio.2006.10.007 Samanya, M., \& Yamauchi, K. (2002). Histological alterations of intestinal villi in chickens fed dried Bacillus subtilis var. natto. Comparative Biochemistry and Physiology Part A: Molecular \& Integrative Physiology. 133(1), 95-104. http://dx.doi.org/10.1016/s1095-6433(02)00121-6
Shi, F., \& Zhu, Y. (2007). Application of statistically-based experimental designs in medium optimization for spore production of Bacillus subtilis from distillery effluent. BioControl, 52(6), 845-853. http://dx.doi.org/10.1007/s10526-0069055-z

Sreena, C.P., Vimal, K.P., \& Denoj S. (2016). Production of cellulases and xylanase from Bacillus subtilis MU S1 isolated from protected areas of Munnar wildlife division. Journal of Microbiology, Biotechnology and Food Science,

5(6), 500-504. http://dx.doi.org/10.15414/jmbfs.2016.5.6.500-504

Tzeng, Y.-M., Rao, Y.K., Tsay, K.-J., \& Wu, W.-S. (2008). Effect of cultivation conditions on spore production from Bacillus amyloliquefaciens B128 and its antagonism to Botrytis elliptica. Journal of Applied Microbiology, 104(5), 1275 1282. http://dx.doi.org/10.1111/j.1365-2672.2007.03683.x

Tuohy, K.M., Pinart-Gilberga, M., Jones, M., Hoyles, L., McCartney, A.L., \& Gibson, G.R. (2007). Survivability of a probiotic Lactobacillus casei in the gastrointestinal tract of healthy human volunteers and its impact on the faecal microflora. Journal of Applied Microbiology, 102(4), 1026-1032. http://dx.doi.org/10.1111/j.1365-2672.2006.03154.x

Wangka-Orm, C., Deeseenthum, S., \& Leelavatcharamas, V. (2014). Low cost medium for spore production of Bacillus KKU02 and KKU03 and the effects of the produced spores on growth of giant freshwater prawn (Macrobrachium rosenbergii de Man). Pakistan Journal of Biological Sciences, 17(8), 1015-1022 http://dx.doi.org/10.3923/pjbs.2014.1015.1022 